\title{
Studies on Therapeutic Value of Naturally Flavored Papaya-Mango Blended Ready-To-Serve (RTS) Beverage
}

\author{
G. Sindumathi*, M.R. Premalatha and V. Kavitha \\ Department of Food Science and Nutrition, Home Science College and Research Institute Tamil \\ Nadu Agricultural University, Madurai- 625 104, Tamil Nadu, India \\ *Corresponding author
}

\section{A B S T R A C T}

There is an abundant potential for therapeutic drinks from fruits in worldwide food industry. In present investigation the efforts have been made to prepare a therapeutic Ready-to-Serve (RTS) made from blend of papaya and mango juice with different naturally flavored extracts. Among different blended ratio $(80: 20,70: 30,60: 40)$ for

\section{Keywords}

Papaya, Mango, Therapeutic RTS, Flavoring extracts, Glass bottles.

\section{Article Info}

Accepted:

07 October 2017

Available Online:

10 December 2017 prepared RTS, the ratio of 50:50 was reached the highest sensory scores for overall acceptability. Extracts of ginger + cardamom in the ratio of 1:1 was found to be more suitable as flavoring agents in papaya and mango blended RTS beverage. The prepared RTS beverage was bottled in glass bottles stored in room temperature. The acid content of developed beverage increased for 0.25 to 0.36 per cent in stored samples. The freshly prepared papaya mango RTS beverage has TSS of $15^{\circ} \mathrm{bx}$ and slight reduction was noticed during storage. A gradual increase in reducing sugar and total sugar content of the developed RTS was observed with the values of $3.16 \mathrm{~g} / 100 \mathrm{~g}$ to $4.20 \mathrm{~g} / 100 \mathrm{~g}$ and 12.00 to $13.78 \mathrm{~g} / 100 \mathrm{~g}$ respectively. The initial and final ascorbic acid content was $8.50 \mathrm{mg} / 100 \mathrm{~g}$ and $8.04 \mathrm{mg} / 100 \mathrm{~g}$ was observed. The final $\beta$ carotene content of RTS beverage decreased from $875 \mu \mathrm{g} / 100 \mathrm{~g}$ to $856 \mu \mathrm{g} / 100 \mathrm{~g}$ during storage. Microbial load of prepared RTS was below detectable level (BDL) at the end of the storage. The overall acceptability score for RTS beverage was 8.3 in a 9 point hedonic scale. The cost of production of naturally blended RTS beverage has been worked out to Rs 6.00/200 ml. It could be recommended for the large scale production at industrial level.

\section{Introduction}

Consumption of fruit and vegetables is recommended as part of a healthy diet once these are rich sources of phytochemicals as carotenoids, polyphenols, vitamins and minerals, besides presenting complex carbohydrates and fibers (Heber, 2004). Moreover, epidemiological studies have established a relationship between fruit and vegetable consumption and prevention of human diseases (Kaisoon et al., 2012).
However, changes in modern life-style led consumers to decrease the intake of fresh produce (Zhou et al., 2015).

Papaya (Carica papaya) fruit belongs to species in genus Carica of the plant family Caricaceae, widely distributed throughout the tropics including India. It is known as common fruit due to its reasonable price. Papaya is a very wholesome fruit with high 
nutritive and medicinal value. Papaya is rich in antioxidant nutrients such as carotenes, flavonoids and vitamin $\mathrm{C}$ as well as vitamin $\mathrm{B}$ (folate and pantothenic acid). It is also a good source of fiber and minerals such as magnesium. These nutrients help to improve cardiovascular health and protect against colon cancer (Anonymous, 2017).

Mango (Mangifera indica L.) is one of the most important fruits in terms of production, marketing and consumption throughout tropical and subtropical countries. The fruit is large, fleshy drupe with edible mesocarp and the size and shape vary considerably depending upon the cultivar. It is considered as best fruits of the world by virtue of its succulence, exotic flavor, delicious taste, delicate fragrance, attractive colour, so it is also known as "King of fruit". It has high in several bioactive compounds such as total phenolics, carotenoids, ascorbic acid and dietary fibres (Arauz, 2000).

Some fruits which are rich in nutrients but are not accepted due to high acidity or poor taste and flavor. It can be blended with other fruits to improve their acceptability and make use of available nutrients (Khan et al., 1988). The perishable nature of papaya is a major drawback of the fruits to distant market and storage during glut in the market. Papaya is blended with other fruits, because of its typical flavor of papaya juice after processing is not liked by few consumers. Papaya is of explicit quality with great nutritional, medicinal, organoleptic, economic and traditional importance and it is available in plenty during particular season but all have not been utilized to desired extent. Besides available traditional food products, it could be utilized in development of Fast Moving Consumer Good like RTS beverage. However, consumer trend towards papaya products emphasize the need of its value enhancement with fortification of novel ingredients to promote it as high valued product.

It has been reported that the organoleptic quality of RTS beverage prepared from juice could be increased by the addition of spice extracts of ginger, black pepper, mint, cardamom and cumin etc. These spices apart from their appetizing properties also possess medicinal and therapeutic values, which have a profound effect on human health, since they affect many functional processes.

Fruit beverages are well enjoyed by all age groups of the society (Balaswamy et al., 2011). Fruit beverages are highly nutritive, refreshing, thirst quenching, appetizing and easily digestible. Blended drinks are good alternative for development of new products to provide benefit of taste, nutrition as well as medicinal properties. The blending of papayamango fruit drinks could be an economic requisite to utilize profitably. Secondly the objective could be to supplement appearance, nutrition and flavor. Thirdly one could think of new product development through blending (Kalra et al., 1991).

Blending of fruit juice helps in improving nutrient elements, reducing cost of production by using less expensive fruits in the blends and also leads to new product developments.

One of the recent trends in the food processing arena is to minimize or avoid the use of synthetic food additives due to the fear of health hazards that can be brought about by the use of food products which contain synthetic food additives. Use of natural colours, flavours, preservatives and blending of different fruits are on the increase. Based on these concepts the study was undertaken to develop therapeutic value of naturally flavored papaya mango blended ready-toserve (RTS) beverage with the following objectives. 
To standardize papaya RTS beverage blended with mango with different proportions.

To standardize blended papaya -mango RTS beverage with different flavor extracts.

To study the nutritional changes in the standardized papaya-mango RTS beverage during storage at room temperature.

\section{Materials and Methods}

\section{Preparation of papaya and mango juice}

The freshly ripe papaya fruits were collected and washed thoroughly in running tap water. Fruits were peeled with the help of stainless steel knife, cut into two half and seeds were removed manually. The freshly ripe mango fruits were washed and peeled using a peeler, seeds removed (Fig. 1).

Then the papaya and mango were the cut into pieces and sized to make them feasible for extraction of pulp. The pulp was extracted separately by using fruit processor followed by filtration through muslin cloth to separate the fibrous particles. The filtrate consisting of partially clarified papaya juice was utilized for preparation of ready-to-serve RTS beverage (Saravana kumar and Manimegalai, 2005).

\section{Preparation of flavoring extracts}

The flavoring agents in the combination of ginger + cardamom, ginger + lime, mint + lime, mint + ginger, mint + cardamom are used in papaya and mango blended RTS beverage. Fifty gram of fresh flavoring agent was mixed in $500 \mathrm{ml}$ of water, boiled for 20 minutes in a closed vessel and cooled. The extract of the flavouring agent was filtered and added in the ratio of $1: 1$ to the RTS beverage in varying proportions $(2,4$ and $6 \mathrm{ml})$.
Standardization of therapeutic blended and flavored papaya-mango RTS beverage

Flavored and blended RTS beverage was prepared using $15 \%$ of total soluble solids (TSS) and $0.3 \%$ of acidity and 10\% of blended juices of different blending ratio of (A) $70 \%$ papaya juice $+30 \%$ mango juice, (B) $60 \%$ papaya juice $+40 \%$ mango juice, (C) $50 \%$ papaya juice $+50 \%$ mango juice and (D) $80 \%$ papaya juice $+20 \%$ mango juice. In the best blending ratio of papaya and mango RTS beverage the extracts of flavoring agent was added in varying proportions. Best blended and flavored RTS beverage was selected by organoleptic test which was conducted on 9 point Hedonic scale for appearance, colour, taste, flavor and overall acceptability by a panel of 25 semi trained judges having prior experience of sensory evaluation of fruits and vegetable product.

\section{Interval of analysis}

The therapeutic RTS beverage with best blending combination and their ratio (on the basis of sensorial evaluation) was packed in glass bottles and kept at room temperature and changes were determined during at once in twenty days up to four months and for the discussions the initial, 60th day and final values were taken. Physico-chemical parameters were measured by standard method and overall acceptability was measured on 9 point Hedonic Scale by 20 semi-trained panel members.

\section{Physico- chemical parameters}

The physico-chemical qualities of the prepared therapeutic RTS beverage samples were analyzed using recommended standard of Association of Official Analytical Chemists methods (AOAC, 2005). Fruit juices were analyzed initially for total soluble solids by using a hand refractometer (Erma, 
Japan) and the values were expressed as ${ }^{\circ}$ Brix. The $\mathrm{pH}$ was determined by an electronic $\mathrm{pH}$ meter (Mettler oledo, UK). The titrable acidity was determined by titrating the RTS beverage of various concentrations with standard alkaline and the results were expressed as percentage of anhydrous citric acid. Ascorbic acid content of beverages was titrimetrically estimated by indophenol dye method as described by Ranganna (1995). Lane-Eynon method was performed to determine the total sugar content of the beverages. The $\beta$-carotene of the sample was estimated calorimetrically as described by Raghuramulu et al., (1983).

\section{Statistical analysis}

The data generated during experimentation were recorded and statistically analyzed using standard procedure for analysis of completely randomized block design (CRD) as per the method suggested by the Panse and Sukhatme (1985). The standard errors (SE) and critical differences (CD) at 5\% level of significance were worked out for comparison of treatments and presented in the tables.

\section{Microbial examination of the products}

The sample was serially diluted. Dilution of $10^{-5}$ and $10^{-6}$ was taken for all the analysis. One $\mathrm{ml}$ of the serially diluted sample was taken in petridishes and appropriate media was added for the specific organism. The plates were incubated at room temperature for 24 hours for bacteria; 72 hours for fungi and the colonies were counted (Istavankiss, 1984).

\section{Results and Discussion}

\section{Standardization of papaya-mango RTS beverage}

According to FPO standards, RTS fruit beverage should contain at least $10 \%$ fruit juice and $10 \%$ TSS besides about $0.3 \%$ acid.
It was found that only $62-68 \%$ of the pulp could be extracted for the fruit because rest of pulp fraction was mixed with fibre. The papaya and mango fruit pulps were blended in various ratios 80:20, 70:30, 60:40, 50:50. Mean scores obtained for the various proportions are given in Table 1. Also it was observed that the organoleptic rating in terms of colour, appearance, flavor, taste and overall acceptability was above 9.0 in 50:50 proportions of papaya -mango blended RTS beverage. Papaya fruits are rich in nutrients but are not accepted due to high acidity or poor taste and flavor.

Therefore, by blending the fruit juices of kinnow, pear and grapes with a small quantity of strongly flavored vitamin rich fruit juice, blends can be prepared for commercial exploitation by the processing industry (Sooch et al., 1995).

\section{Standardization of flavoring extracts in the papaya-mango RTS beverage}

Single and combination of flavor extracts were added to papaya-mango blended RTS beverage in various quantities and evaluated the organoleptic characteristics by a panel of judges. Mean scores obtained for the papayamango blended RTS beverage are given in Table 2 .

The data on effects of combination on overall acceptability suggested that the beverage prepared by 1:1 proportion of ginger + cardamom $(2 \mathrm{ml})$ was liked by the judges on the basis of maximum score recorded for almost all the sensory parameters as compared to the rest of combinations (ginger + lime, mint + lime, mint + ginger, mint + cardamom). This might be associated with slight bitter taste and unpleasant colour of extracts. Bhardwaj and Mukherjee (2005) also observed that the juice blended with kinnow juice $(87.0 \%)+$ pomegranate juice $(10.0 \%)+$ ginger juice $(3 \%)$ and kinnow juice $(92.0 \%)+$ 
aonla juice $(5.0 \%)+$ ginger juice $(3.0 \%)$ had minimum changes in the physic-chemical and sensory score with minimum increase in microbial population upto six months of storage. These spices, apart from their appetizing properties also possess medicinal and therapeutic values, which have a profound effect on human health, since they affect many functional processes.

Nutrient content of therapeutic flavoured and blended papaya-mango RTS beverage during storage

The data obtained on nutrient content such as $\mathrm{pH}$, TSS acidity, reducing sugar, total sugar, vitamin $C$ and $\beta$-carotene in Table 3 shows that the storage period had statistically significant effect on the flavored and blended papaya-mango RTS beverages.

\section{pH}

A gradual and slight reduction in the $\mathrm{pH}$ of RTS was observed during storage. The initial value of the $\mathrm{pH}$ of RTS was 4.65 which had changed to 4.84 at the end of the storage period. The increase in $\mathrm{pH}$ values might be due to decrease the formation of acids during various bio-chemical processes during storage. The results obtained are in conformity with those of earlier results (Patel et al., 2013) with respect to papaya-mango blended pulp stored at room temperature for the period of six months.

\section{Acidity (\%)}

Acidity in therapeutic flavored papaya-mango RTS beverage increased from 0 day $(0.25 \%)$ to $60^{\text {th }}$ day $(0.29 \%)$ and $120^{\text {th }}$ day $(0.36 \%)$. The increase in acidity per cent might be due to either the bio-conversion of acids in to sugars or formation of acidic compounds by degradation and oxidation of reducing sugars due to the breakdown of peptic bodies.

Similar types of results were also reported by Oyeleke et al., (2013). It indicated that the titrable acidity increases as the addition of pineapple juice to the watermelon increases during storage period.

\section{Total soluble solids $\left({ }^{\circ} \mathrm{brix}\right)$}

The initial TSS content of therapeutic flavored and blended papaya-mango RTS beverage was $15.0^{\circ}$ brix which was increased to $19.0^{\circ} \mathrm{bx}$ at 120 days of storage. Increase in TSS during storage might be attributed in conversion of polysaccharides and other constituents of juice into sugar. Boghani et al., (2012) also observed an increase in the TSS of developed papaya-Aloe vera (13.30 ${ }^{\circ} \mathrm{bx}$ ) ready-to serve beverage.

Table.1 Mean sensory scores obtained for the papaya-mango RTS beverage

\begin{tabular}{|l|c|c|c|c|}
\hline \multirow{2}{*}{ Sensory Characteristics } & \multicolumn{4}{|c|}{ Various proportions of papaya-mango RTS beverage } \\
\cline { 2 - 5 } & $\mathbf{8 0 : 2 0}$ & $\mathbf{7 0 : 3 0}$ & $\mathbf{6 0 : 4 0}$ & $\mathbf{5 0 : 5 0}$ \\
\hline Colour & 9.0 & 9.0 & 9.0 & 9.0 \\
\hline Appearance & 9.0 & 9.0 & 9.0 & 9.0 \\
\hline Flavor & 7.0 & 7.0 & 7.0 & 9.0 \\
\hline Taste & 7.0 & 7.0 & 8.0 & 9.0 \\
\hline Overall acceptability & 6.0 & 6.0 & 7.0 & 9.0 \\
\hline
\end{tabular}


Table.2 Mean scores obtained for the flavoring extracts in the papaya-mango RTS beverage

\begin{tabular}{|c|c|c|c|c|c|}
\hline \multirow{2}{*}{$\begin{array}{l}\text { Blended flavoring extracts used in } 200 \\
\text { ml of papaya-mango blended RTS } \\
\text { beverage }\end{array}$} & \multicolumn{5}{|c|}{$\begin{array}{l}\text { Mean scores obtained for the various sensory } \\
\text { parameter }\end{array}$} \\
\hline & $\frac{\overline{0}}{0}$ & 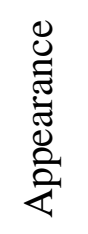 & 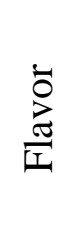 & 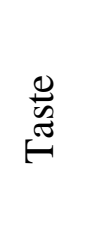 & 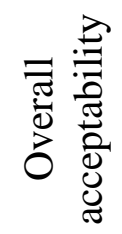 \\
\hline \multicolumn{6}{|c|}{ Ginger + cardamom $(1: 1)$} \\
\hline $2 \mathrm{ml}$ & 9.0 & 9.0 & 9.0 & 9.0 & 9.0 \\
\hline $4 \mathrm{ml}$ & 9.0 & 8.0 & 8.0 & 8.0 & 8.0 \\
\hline $6 \mathrm{ml}$ & 9.0 & 7.0 & 7.0 & 6.0 & 8.0 \\
\hline \multicolumn{6}{|c|}{ Ginger + lime $(1: 1)$} \\
\hline $2 \mathrm{ml}$ & 9.0 & 8.0 & 8.0 & 7.0 & 8.0 \\
\hline $4 \mathrm{ml}$ & 9.0 & 9.0 & 8.0 & 8.0 & 7.0 \\
\hline $6 \mathrm{ml}$ & 9.0 & 8.0 & 7.0 & 6.0 & 8.0 \\
\hline \multicolumn{6}{|c|}{ Mint + lime $(1: 1)$} \\
\hline $2 \mathrm{ml}$ & 8.0 & 8.0 & 8.0 & 7.0 & 7.0 \\
\hline $4 \mathrm{ml}$ & 8.0 & 7.0 & 8.0 & 6.0 & 8.0 \\
\hline $6 \mathrm{ml}$ & 8.0 & 7.0 & 8.0 & 6.0 & 8.0 \\
\hline \multicolumn{6}{|c|}{ Mint + ginger $(1: 1)$} \\
\hline $2 \mathrm{ml}$ & 8.0 & 8.0 & 8.0 & 7.0 & 7.0 \\
\hline $4 \mathrm{ml}$ & 8.0 & 7.0 & 7.0 & 7.0 & 8.0 \\
\hline $6 \mathrm{ml}$ & 8.0 & 6.0 & 6.0 & 7.0 & 7.0 \\
\hline \multicolumn{6}{|c|}{ Mint + cardamom $(1: 1)$} \\
\hline $2 \mathrm{ml}$ & 8.0 & 8.0 & 8.0 & 7.0 & 8.0 \\
\hline $4 \mathrm{ml}$ & 8.0 & 7.0 & 7.0 & 7.0 & 8.0 \\
\hline $6 \mathrm{ml}$ & 8.0 & 8.0 & 7.0 & 8.0 & 7.0 \\
\hline
\end{tabular}

Table.3 Changes of nutrient content in therapeutic flavoured and blended papaya- mango RTS beverage during storage

\begin{tabular}{|l|l|l|l|l|l|}
\hline \multirow{2}{*}{ Nutrients } & \multicolumn{3}{|c|}{ Storage days } & \multirow{2}{*}{ SED } & \multirow{2}{*}{ CD 0.05 } \\
\cline { 2 - 4 } & 0 day & $\mathbf{6 0}$ days & $\mathbf{1 2 0}$ days & & \\
\hline $\mathrm{pH}$ & 4.65 & 4.70 & 4.84 & 0.0071 & $0.02500^{* *}$ \\
\hline Acidity $(\%)$ & 0.25 & 0.27 & 0.36 & 0.0100 & $0.0318^{* *}$ \\
\hline TSS $\left({ }^{\circ}\right.$ brix $)$ & 15.00 & 17.50 & 19.00 & 0.0122 & $0.0390^{* *}$ \\
\hline Reducing sugar $(\mathrm{g} / 100 \mathrm{~g})$ & 3.16 & 3.39 & 4.20 & 0.0058 & $0.0184^{* *}$ \\
\hline Total sugar $(\mathrm{g} / 100 \mathrm{~g})$ & 12.00 & 12.52 & 13.78 & 0.0141 & $0.0450^{* *}$ \\
\hline Ascorbic acid $(\mathrm{mg} / 100 \mathrm{~g})$ & 8.50 & 8.17 & 8.04 & 0.0066 & $0.0132^{* *}$ \\
\hline$\beta$-carotene $(\mu \mathrm{g} / 100 \mathrm{~g})$ & 875 & 864 & 856 & 0.0042 & $0.0084^{* *}$ \\
\hline
\end{tabular}


Table.4 Organoleptic characteristics of therapeutic flavored and blended papaya-mango RTS beverages during storage

\begin{tabular}{|l|c|c|c|c|}
\hline \multirow{2}{*}{ Storage days } & \multicolumn{4}{|c|}{ Sensory attributes } \\
\cline { 2 - 5 } & Colour & Flavor & Taste & Overall acceptability \\
\hline 0 day & 9.0 & 9.0 & 9.0 & 9.0 \\
\hline $60^{\text {th }}$ day & 8.9 & 8.6 & 8.4 & 8.5 \\
\hline 120 day & 8.6 & 8.4 & 8.2 & 8.3 \\
\hline
\end{tabular}

Fig.1 Process flow chart for preparation of flavored papaya-mango blended RTS beverage

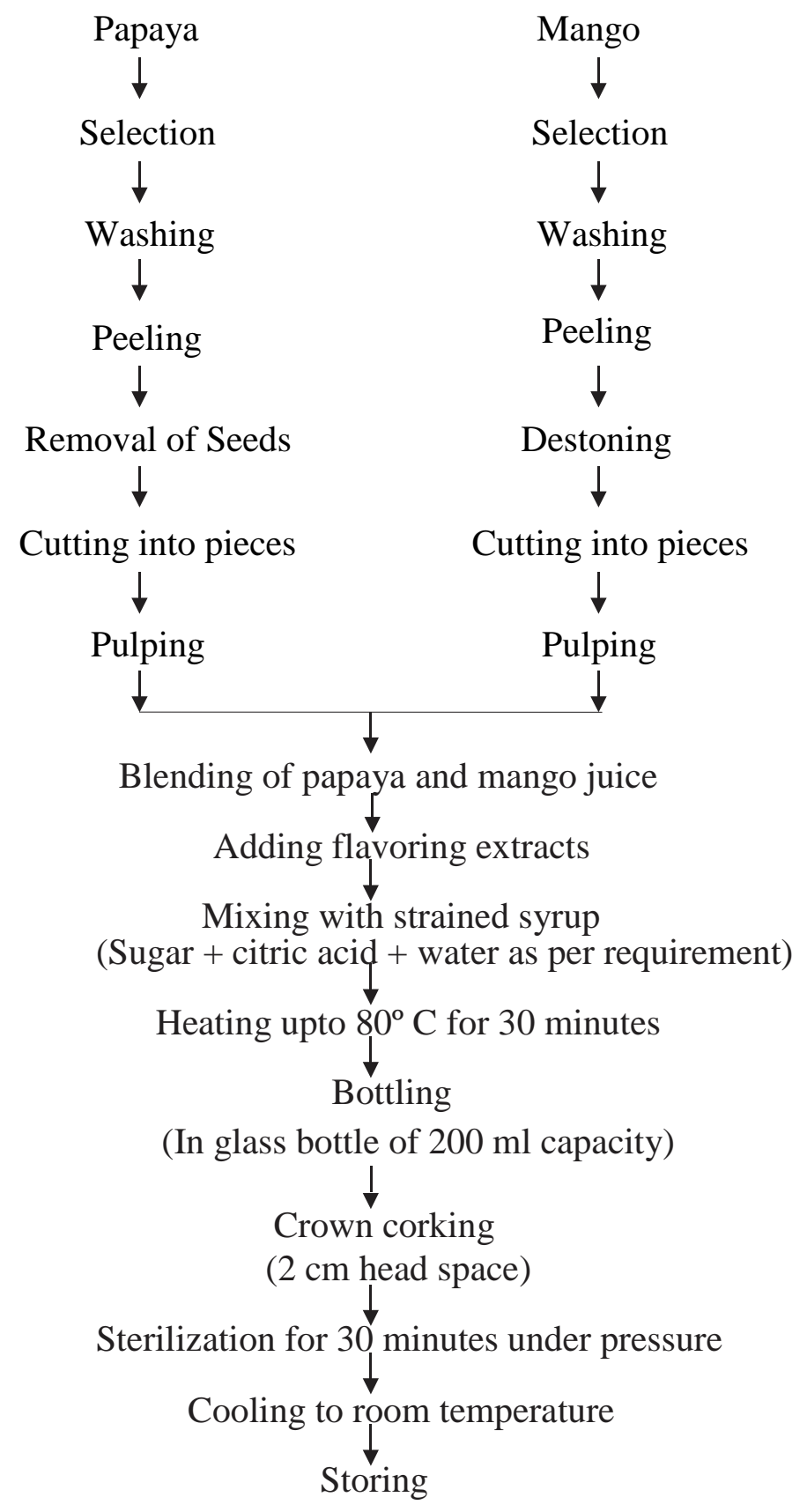




\section{Reducing sugar (g/100g)}

The reducing sugar of therapeutic flavored and blended papaya-mango RTS beverage changed significantly during storage. The reducing sugars increased significantly from 0 day $(3.16 \mathrm{~g} / 100 \mathrm{~g})$ to $120^{\text {th }}$ day $(4.20 \mathrm{~g} / 100 \mathrm{~g})$. The increase in reducing sugars may be due to the release of monomers by hydrolysis of polysaccharides in the presence of citric acid. Balaswamy et al., (2013) also observed a gradual increase in reducing sugar level in developed smoothies from fruit pulp like mango, papaya, sapota, banana; juices from green grapes and pineapple were blended at various proportions (10-60\%) during six month storage period.

\section{Total sugars $(\mathrm{g} / \mathbf{1 0 0 g})$}

It was noted that the total sugar content of the therapeutic flavored and blended papaya-mango RTS beverage had increased from the initial value of $12.00 \mathrm{~g} / 100 \mathrm{~g}$ to $13.78 \mathrm{~g} / 100 \mathrm{~g}$ at the end of the storage period. The increase in total sugar content might be due to the accelerated hydrolysis of insoluble polysaccharides and other carbohydrates polymer and inversion of sugar on account of high amount of fixed acidity. The results obtained are in conformity with those of earlier results (Sakhale et al., 2012) with respect to whey-based papaya pulp blended RTS beverage stored at refrigeration temperature for the period of three months.

\section{Ascorbic acid (mg/100g)}

There was a significant decrease in ascorbic acid content of therapeutic flavored and blended papaya-mango RTS beverage as the storage period increased. On the initial day RTS beverage had high ascorbic acid content (8.50 $\mathrm{mg} / 100 \mathrm{~g}$ ) which significantly decreased to a greater extent by the $60^{\text {th }}$ day $(8.17 \mathrm{mg} / 100 \mathrm{~g})$ decreased more at the end of the storage period. The decrease in the ascorbic acid content might be due to oxidation of vitamin-C by trapped oxygen in glass bottles, which resulted in formation of dihydroascorbic acid and also due to the effect of processing, storage time and exposure to light. Similar results also noted by Amaravathi et al., (2014) that the decreasing trend of ascorbic acid content $(5.60 \%)$ with increase in the storage period in spiced pineapple RTS beverage.

\section{$\beta$-carotene $(\mu \mathrm{g} / \mathbf{1 0 0 g})$}

The $\beta$ carotene content of the therapeutic blended and flavored papaya-mango RTS beverage recorded a steady decrease from an initial value of $875 \mu \mathrm{g} / 100 \mathrm{~g}$ to $856 \mu \mathrm{g} / 100 \mathrm{~g}$. The total carotenoids content decreased significantly in all the beverages due to oxidative breakdown, isomerization or enzymatic destruction of the pigments. Dhaliwal and Hira (2004) reported that increase in $\beta$-carotene contents in spinach and pineapple juice blended with carrot juice. They also reported a minimum (52.02\%-61.41\%) loss in $\beta$-carotene content during six months storage of juice blended with carrot-spinach and carrot pineapple juice. Deka et al., (2005) reported that the total carotenoid content decrease minimally over a period of six months storage in mango-pineapple spiced beverage.

\section{Enumeration of microbial load in therapeutic flavoured and blended papaya- mango during storage}

The results obtained for microbial load in therapeutic flavored and blended papaya-mango during storage. Initially there was no bacterial count in flavored and blended papaya-mango during storage. It had increased to $2.00 \times 10^{-6}$ after 120 days of storage. No fungal growth was noticed in flavored and blended papaya-mango RTS beverage in the entire period of storage period. Minimum increase in the microbial population was recorded when juice was blended with spices like ginger, mint and black pepper. This might be due to the inhibitory effect of spices towards micro-organisms. Spiced extract and juice has been used for prolonging the keeping quality of juice and reducing their spoilage. The possible reason may be that spiced extracts have antibacterial 
properties which check the oxidation of juice constituents and growth of micro-organisms. Ejechi et al., (1998) reported that heating mango juice to $55^{\circ} \mathrm{C}$ for 15 minutes and supplementing with nutmeg $(4 \% \mathrm{v} / \mathrm{v})$ and ginger $(4 \% \mathrm{v} / \mathrm{v})$ markedly inhibited microbial growth. Similarly, microbiological examination revealed that the pear and apricot blends (80:20) can be stored at room temperature for six months without any spoilage (Attri et al., 1998). Similar results of the total plate count from whey based mango RTS beverage was observed by Sakhale et al., (2012).

Changes in overall organoleptic quality of therapeutic flavored and blended papaya-mango RTS beverage on the day of preparation and after storage for 120 days are shown in Table 4. The therapeutic RTS beverage scored good $(>8)$ in sensory evaluation after 120 days of storage period. Organoleptic quality like color, flavor and nutritive value of fruit products generally reduces with the increase in storage period (Bhardwaj and Shruti, 2011). The results were in agreement with data reported by Boghani et al., (2013) who developed RTS beverage using $10 \%$ Aloe Vera and $90 \%$ papaya blends with good (8.0) overall quality during storage period of six months.

From the results of the present study, it can be concluded that a therapeutic flavored and blended papaya-mango RTS beverage can be prepared successfully with the incorporation of $2 \%$ ginger and cardamom extracts.. It can be stored at ambient condition in sterilized bottles for 120 days without showing any symptoms of microbial spoilage. Hence it is finally concluded that when compared to soft drinks, flavored and blended papaya-mango RTS beverage provide nutrients like ascorbic acid and $\beta$-carotene which are also antioxidant essential to maintain health. Papaya, mango, ginger and cardamom known for their nutritional and medicinal properties as well recognized by Indian Ayurveda also can be exploited to develop nutritious health drinks with inherent therapeutic properties. Blending of fruit juices help in improving nutritional and sensory quality and reduce cost of production by using seasonal low cost fruits leading to new product development. Commercialization of these products helps in utilizing various perishable seasonal fruits into nutrient rich value added products, which in turn balances the economic aspects.

\section{References}

Amaravathi, T., Vennila, P., Hemalatha, G and Parimalam, P. 2014. Spiced pineapple Ready-To-Serve beverages. Indian Journal of Science and Technology. 7(11): 1827-1831.

AOAC. 2005. Official methods of analysis $\left(16^{\text {th }}\right.$ edition), association of Official Analytical Chemists, Washington, USA.

Anonymous, 2017. www.organicfacts.net

Arauz L. 2000. Mango anthracnose: economic impact and current options for integrated management. Plant Dis 84-600-611.

Attri, B.L., LAL, B.B and Joshi, V.K. 1998. Physico-chemical characteristics, sensory quality and storage behavior of sand pear juice blended with temperate fruit juice/pulps. Indian Food Packer. 52:3638.

Balaswamy, K., PrabhakaraRao, P.G., Nagender, A., NarsingRao, G., SathiyaMala, K., Jyothirmay, T., Math, R.G. and Satyanarayana, A. 2013. Development of smoothies from selected fruit pulps/juices. International Food Research Journal 20(3):1181-1185.

Bhardwaj, R.L and Shruti, P. 2011. Juice blends- A way of utilization of underutilized fruits, vegetables and spices: A review. Critical Reviews in Food Science and Nutrition. 51:6. 563-570.

Bhardwaj, R.L and Mukherjee, S. 2005. Studies on preservation of kinnow mandarin juice and its blends. Ph.D. Dissertation. Department of Horticulture. SKN. College of Agriculture. Jobner, RAUBikaner.

Boghani, A.K., Abdul, R and Syed, I. H. 2012. Development and storage studies of blended papaya Aloe vera Ready to Serve 
(RTS) beverage. Food Processing Technology. 3(10): 13-18.

Deka, B.C., Dethi, V and Saikia, A. 2005. Changes in quality of mango-pineapple spicd beverage during storage. Indian Journal of Horticulture. 62:71-75.

Dhaliwal, $M$ and Hira, C.K. 2004. Effect of storage on physico-chemical and nutritional characteristics of carrotspinach and carrot-pineapple juice. Journal of Food Science and Technology. 41:613-617.

Ejechi, B.O., Souzey, J.A. and Akpomedaya, D.E 1998. Microbial stability of mango juice preserved by combined application of mild heat and extracts of two tropical spics. Journal of Food Protection. 61:725728.

Heber, D 2004. Vegetables, fruits and phytoestrogens in the prevention of diseases. Journal of Post graduate Medical 50: 145-149.

Istavankiss, S.S. 1884. Testing methods in food microbiology. Elsevier publication limited. p 95-97.

Kaisoon O, Konczak I, Siriamornpun, S 2012. Potential health enhancing properties of edible flowers from Thailand. Food Research International 46:563-571.

Kalra, S.K., Tandon, D.K and Singh, B.P. 1991. Studies on evalauation of mango-papaya blended beverage. Indian Food Packer. 45(1):33-36.

Khan, A., Singh, H., Krishna, B.R and Bhatia, A.K. 1988. Carotene enriched beverages. Indian Food Packer. 21(1):27-29.

Nagarajan., 2002. Nutrient importance of papaya. Kissan

Nunez, Selles, A.J., Paes. 2002. Medicinal properties of mango. Food patents. 24(1): 1

Oyeleke, G.O., Ajao, F.D., and Adetoro, R.O.
2013. Development and analysis of blended pineapple-watermelon Ready To Drink RTD juice. Journal of Environmental Science, Toxicology and Food Technology. 4(6): 22-24.

Panse, V.G and Sukhatme, P.V. 1985. Statistical method for agricultural workers. Indian Council of Agricultural Research, New Delhi.

Patel, A.N., Ray, N.R., Chavada, J.C, and Patel, K.A. 2013. Evaluation of mango-papaya blended pulp and its storage behavior cv. Mallika, Amrapalliand Totapuri. The Asian Journal of Horticulture. 8(1):84-87.

Raghuramulu, K., Nair, M and Kalyan sundar, S. 1983. A manual of laboratory techniques. National Institute of Nutrition. ICMR, Hyderabad, India, 129130.

Ranganna, S. 1995. Hand book of Analysis and quality control for fruit and vegetable products. Tata McGraw Hill Publishing Co., Ltd. New Delhi.

Sakhale, B.K., Pawar, V.N and Ranveer, R.C. 2012. Studies on the development and storage of whey based RTS beverage from Mango cv. Kesar. Food Processing and Technology. 3(3):13-18.

Saravankumar, R and Manimegalai, G. 2005. Studies on storage stability of whet based papaya juice blended RTS beverage. Journal of Food Sciences and technology 42:185-188.

Sooch, H.S., Sandhu, K.S., Sandhu, J.S. 1995. A juicy affair. Food Technology. 13(2):27-31. World. 28(7):41.

Zhou, G., Gan Y, Miao, M Hamilton K., Knoll N, Schwarzer R 2015. The role of action control and action planning on fruit and vegetable consumption. Appetite 91:6468.

\section{How to cite this article:}

Sindumathi, G., M.R. Premalatha and Kavitha, V. 2017. Studies on Therapeutic Value of Naturally Flavored Papaya-Mango Blended Ready-To-Serve (RTS) Beverage. Int.J.Curr.Microbiol.App.Sci. 6(12): 878-887. doi: https://doi.org/10.20546/ijcmas.2017.612.095 